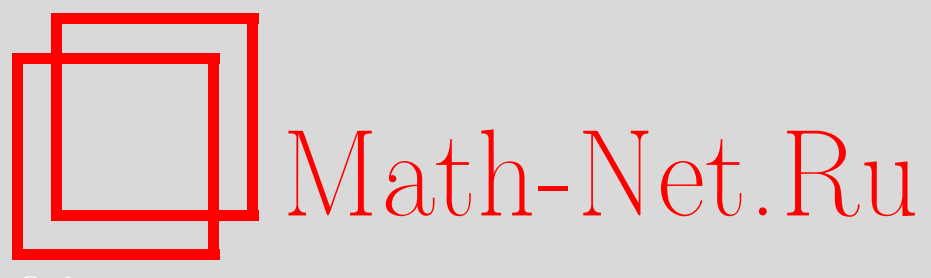

М. С. Агранович, А. В. Бабин, А. С. Демидов, Ю. А. Дубинский, А. И. Комеч, С. Б. Куксин, А. П. Кулешов, В. П. Маслов, С. П. Новиков, В. М. Тихомиров, А. В. Фурсиков, В. В. Чепыжов, А. И. Шнирельман, М. А. Шубин, Г. И. Эскин, Марко Иосифович Вишик (некролог), УМН, 2013, том 68, выпуск 2, 197-200

DOI: https://doi.org/10.4213/rm9515

Использование Общероссийского математического портала Math-Net.Ru подразумевает, что вы прочитали и согласны с пользовательским соглашением http://www.mathnet.ru/rus/agreement

Параметры загрузки:

IP : 54.224 .187 .69

26 апреля 2023 г., 16:04:25

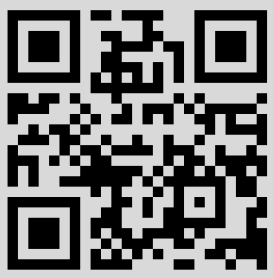




\section{Марко Иосифович Вишик}

23 июня 2012 г. ушел из жизни Марко Иосифович Вишик, выдающийся математик, крупнейший специалист и один из основоположников теории дифференциальных уравнений с частными производными.

М.И. Вишик родился 19 октября 1921 г. во Львове. В 8 лет потерял отца. Он очень нежно вспоминал мать, которая смогла дать ему образование, несмотря на материальные трудности.

В 1937 г. М.И. Вишик окончил львовскую классическую гимназию, а в 1939 г. - физико-математический лицей. Уже в лицее он привлек внимание преподавателей своим оригинальным математическим мышлением.

В декабре 1939 г. Марко Иосифович был зачислен на физико-математический факультет Львовского университета, где тогда преподавали С. Банах, Ю. Шаудер, С. Мазур, В. Орлич и многие другие замечательные математики. ${ }^{1}$

Этот период был связан с присоединением За-

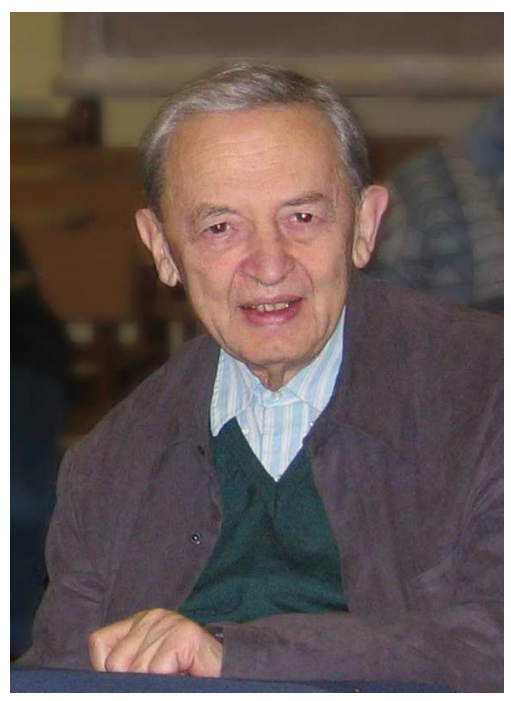
падной Украины к СССР, которое Марко Иосифович воспринял вполне положительно.

28 июня 1941 г. во время дежурства в университете на случай бомбежки, всем комсомольцам (в том числе и М.И. Вишику), желающим сражаться с фашистами, предложили немедленно покинуть город, не заходя домой, поскольку немецкие войска подошли вплотную ко Львову. Так Марко Вишик вынужден был уйти на восток, не попрощавшись с матерью, которую уже никогда больше не увидел, как и других близких - все они погибли.

После нескольких дней безостановочного пути под палящим солнцем и бомбежками Марку Иосифовичу удалось сесть на поезд и за две недели добраться до Киева. Он хотел поступить в армию, чтобы воевать против нацистов. Но в Киеве выяснилось, что "западников" в армию не берут. Из Киева - комсомольская путевка на сельхозработы на Кубани, а осенью - бегство от наступающих немецких войск в Махачкалу, где он поступил в педагогическое училище. Осенью 1942 г. - опять переезд из-за приближения немецких войск, теперь - в Тбилиси.

Той же осенью 1942 г. он поступил на 4-й курс Тбилисского университета, а в 1943-1945 гг. учился у И. Н. Векуа в аспирантуре Тбилисского математического института.

Весной 1945 г. Марко Вишик был командирован президентом АН Грузинской ССР Н. И. Мусхелишвили в Москву, где обучался в аспирантуре МИАН под руководством Л. А. Люстерника и вел активную работу в семинаре И.Г. Петровского. В 1946 г.

\footnotetext{
${ }^{1}$ Подробнее об этом и некоторых последующих периодах жизни Марка Иосифовича можно узнать из его воспоминаний, опубликованных в кн.: В.Б. Демидович, Мехматяне вспоминают, Изд-во МГУ, М., 2008, 103-135; см. также http://bookos.org/book/583286.
}

DOI: $10.4213 / \mathrm{rm} 9515$ 
в День Победы он встретил в МГУ Асю Моисеевну Гутерман, вскоре ставшую его женой и ангелом-хранителем на всю жизнь. В 1947 г. он защитил кандидатскую диссертацию, а в 1951 г. - докторскую.

В 1953-1965 гг. Марко Иосифович преподавал на кафедре математики Московского энергетического института. В 1965 г. по приглашению И. Г. Петровского он перешел в МГУ, где и работал профессором кафедры дифференциальных уравнений механико-математического факультета до 1993 г. С 1993 г. М. И. Вишик - главный научный сотрудник Института проблем передачи информации РАН. В 1966-1991 гг. Марко Иосифович работал по совместительству в Институте проблем механики АН CCCP, а с 1993 г. и до конца жизни - на кафедре общих проблем управления механико-математического факультета МГУ.

Марко Иосифович Вишик - всемирно известный ученый, автор около 300 научных работ, в том числе 8 монографий. (Полный список публикаций М. И. Вишика имеется на сайте http://www.iitp.ru/ru/users/127/publications/.)

В своей докторской диссертации М.И. Вишик сформулировал ставшее классическим определение сильно эллиптической системы, а также решил поставленную И. М. Гельфандом проблему описания общего вида однородных граничных условий, при которых краевая задача для заданного эллиптического дифференциального оператора второго порядка является корректной (в частности, однозначно разрешимой), фредгольмовой или самосопряженной.

В 1950 г. эти результаты Марка Иосифовича были удостоены премии Московского математического общества.

В 1953 г. Марко Иосифович под влиянием работ М. В. Келдыша построил теорию краевых задач для общих эллиптических уравнений второго порядка, вырождающихся степенным образом на части границы области.

Совместная работа М. И. Вишика и С. Л. Соболева 1956 г. посвящена общим постановкам и разрешимости неоднородных краевых задач для эллиптических уравнений в обобщенных функциях. В последующих работах М.И. Вишика была построена современная теория смешанных краевых задач для весьма общих нестационарных уравнений. Эта теория и ее дальнейшее развитие составили основное содержание известных книг Ж. Лионса и Э. Мадженеса по неоднородным краевым задачам.

Широчайшую известность и признание получили совместные работы М.И. Вишика и Л. А. Люстерника 1957-1960 гг. по асимптотике решений сингулярно возмущенных уравнений с малым параметром. Созданные в этих работах методы нашли широкое применение во многих прикладных задачах: в гидромеханике, теории тонких оболочек, теории плазмы, теории дифракции и распространения волн. Индекс цитирования этого цикла работ особенно велик.

В 1960-1963 гг. М.И. Вишик провел глубокое исследование первой и некоторых других краевых задач для квазилинейных эллиптических систем высокого порядка, где ввел ставшее классическим условие монотонности нелинейных операторов, нашедшее широкое применение в целом цикле работ Д. Минти и Ф. Браудера.

К этому же времени относятся работы М. И. Вишика и М. С. Аграновича по общим эллиптическим задачам с параметром в ограниченной области и общим смешанным задачам для параболических уравнений. Предложенный ими метод оказался удивительно эффективен и нашел многочисленные применения, в частности, в теории комплексных степеней и других функций эллиптических операторов.

В выдающемся цикле работ 1963-1968 гг. М. И. Вишика и Г. И. Эскина построена общая теория фредгольмовости краевых задач для эллиптических дифференциальных и псевдодифференциальных уравнений в ограниченной области. Эти работы являются настоящим шедевром аналитических методов в теории уравнений с частными производными. В них впервые проложена связь между корректными краевыми задачами и K-теорией. Эти методы и результаты легли в основу созданной позднее алгебры краевых задач и послужили функциональной основой знаменитой теории индекса.

В 1969 г. М. И. Вишик в серии работ с В. В. Грушиным вернулся к изучению краевых задач для вырождающихся эллиптических уравнений, но уже в общей постановке, позволившей правильно выделить главную часть оператора и определить нужное число граничных условий. 
Работы 1971-1974 гг. с П. М. Блехером, а также с А. В. Марченко посвящены исследованию дифференциальных и псевдодифференциальных операторов на функциях от бесконечного числа независимых переменных, которые были навеяны проблемами квантовой теории поля.

С 1973 г. М. И. Вишик снова занялся исследованием нелинейных уравнений в частных производных, но с совершенно новых позиций. В обширном цикле работ М. И. Вишика и А.В. Фурсикова изучены функционально-аналитические разложения по начальным данным решений квазилинейных параболических уравнений и системы Навье-Стокса, а также впервые введены и изучены пространственно-временные статистические решения и трансляционно однородные статистические решения квазилинейных параболических уравнений и системы Навье-Стокса. Эти работы вошли в монографию, изданную в 1980 г. на русском, в 1986 г. - на немецком и в 1988 г. на английском языке. В работах М. И. Вишика и А. И. Комеча 1973-1982 гг. построены статистические решения системы Навье-Стокса при флуктуациях внешних сил типа белого шума. Эти результаты недавно получили блестящее развитие в работах об эргодичности 2-мерной системы Навье-Стокса учеников Марка Иосифовича и постоянных участников его семинаров С. Б. Куксина и А. Р. Ширикяна.

В 1980-е годы М. И. Вишик и А. В. Бабин, по следам пионерской работы О. А. Ладыженской, заложили основы теории аттракторов нелинейных эволюционных уравнений с частными производными. Они исследовали структуру глобальных аттракторов, получили новые оценки сверху и снизу для их размерности, заложили основы теории возмущения и приближения аттракторов. Все эти замечательные результаты были систематизированы в монографии, быстро получившей всеобщее признание, изданной в 1989 г. на русском, а в 1992 г. - на английском языке.

С 1990-х годов М. И. Вишик и В.В. Чепыжов построили общую теорию глобальных аттракторов неавтономных эволюционных уравнений математической физики, исследовав сложность аттракторов, их колмогоровскую эпсилон-энтропию и энтропийную размерность. В эти же годы М.И. Вишик с С. В. Зеликом получили интересные результаты, касающиеся аттракторов нелинейных эллиптических уравнений в цилиндрических областях.

В 2000-е М.И. Вишик совместно с В.В. Чепыжовым разработали метод траекторных аттракторов, позволивший строить динамические системы и аттракторы для уравнений математической физики, для которых не доказана или не имеет места теорема единственности решения задачи Коши, например, для 3-мерной системы Навье-Стокса. Этим и другим вопросам была посвящена их монография "Attractors for equations of mathematical physics", опубликованная в 2002 г.

М.И. Вишик часто цитировал мнение Д. Гильберта, что тему исследований надо менять каждые четыре года. Он чрезвычайно ответственно относился к выбору тематики своих исследований. Задачи, которые изучал М. И. Вишик, всегда актуальны и часто подсказаны проблемами в прикладных областях - в механике и теоретической физике. Фундаментальные достижения М.И. Вишика в целом ряде областей теории уравнений с частными производными оказали и оказывают существенное влияние на ее развитие, открывая новые пути.

Работы Марка Иосифовича получили широкое признание во всем мире. Он был приглашенным докладчиком на Международных математических конгрессах - в 1966 г. в Москве и в 1974 г. в Ванкувере, принимал участие в подготовительной работе секции дифференциальных уравнений Международных математических конгрессов 1970 и 1978 гг.

В 1974 г. М. И. Вишик был награжден именной медалью Коллеж де Франс. Его постоянно приглашали в ведущие научные центры Европы и Америки, где он читал лекции, знакомился с работами коллег, инициировал новые исследования.

В 1990 г. М. И. Вишик был избран почетным членом Американской Академии Искусств и Наук, а в 1994 г. - членом Национальной Академии Сорока (Италия) и Соросовским профессором. В 1992 г. Российская академия наук присудила Марку Иосифовичу премию имени И. Г. Петровского, а в 1996 г. ему была присуждена премия имени Александра фон Гумбольдта (Германия). В 2001 г. он получил звание почетного доктора Свободного Берлинского университета (doctor honoris causa). 
В течение ряда лет М.И. Вишик был членом редколлегий журналов "Математический сборник", "Asymptotic Analysis", а также сборника переводов "Математика".

Отдельно следует остановиться на педагогической деятельности Марка Иосифовича. Его замечательные лекции довелось слушать тысячам студентов МЭИ и МГУ. Они были так популярны, что по просьбе коллег он читал публичные лекции в МГУ о том, как надо читать лекции!

М. И. Вишик руководил различными научными семинарами, в том числе много лет вел на мехмате МГУ совместно с В. И. Арнольдом, С. П. Новиковым и О. А. Олейник семинар им. И.Г. Петровского по математическим проблемам современной физики. Организованный им в 1961 г. в МГУ семинар по дифференциальным уравнениям Марко Иосифович считал одним из главных дел своей жизни. Все эти годы семинар проводился каждый понедельник, без исключений, вплоть до конца апреля 2012 г., т.е. фактически до последних дней его жизни. Он собирал цвет математического сообщества, и выступать на нем было весьма почетным делом. Требования к докладчикам были чрезвычайно высокими, но предъявлялись всегда в весьма тактичной форме. Семинар в ИППИ по нелинейному анализу, основанный М. И. Вишиком и М. А. Красносельским, продолжает активно работать.

На семинарах Марка Иосифовича выросли его многочисленные ученики, среди которых 57 кандидатов наук; более 30 из них защитили докторские диссертации. Но круг математиков, испытавших на себе благотворное научное влияние Марка Иосифовича, конечно, значительно шире.

Особо следует сказать о внимании, которое Марко Иосифович уделял своим ученикам. Он работал с ними, не считаясь со своим временем: тщательнейшим образом правил их статьи, курсовые и дипломные работы, терпеливо учил их всему необходимому: алгебре, теории меры, топологии. При этом охотно учился и у них, всегда с полным уважением выслушивая мнения студентов и аспирантов. Некоторых учеников он поддерживал материально после окончания аспирантуры, чтобы они смогли защитить диссертации.

Марко Иосифович был удивительно простым и доступным в общении, его скромность, благожелательность и объективность были неподдельны, а чувство юмора совершенно замечательно. Науку он считал коллективным делом, а себя всегда видел в числе работников-исполнителей. Неизменно радовался успехам коллег, и еще больше - студентов и аспирантов. Его безукоризненная манера поведения была общеизвестна и служила образцом для всех, с кем он соприкасался.

Замечательные научные достижения М. И. Вишика - следствие не только его одаренности, но и исключительного трудолюбия. Его организованность и самодисциплина поражали всех: ежедневно подъем в 7:00, зарядка до 8:00, в 9:00 - за рабочим столом, 20:00 - прогулка, 21:00 - сон. Каждое воскресенье - поход с друзьями в Подмосковье на 20-30 километров.

Неоценимую поддержку в жизни и работе Марку Иосифовичу оказывала его жена, с которой он прожил 63 года в любви и преданности. Ася Моисеевна прекрасно понимала научное значение Марка Иосифовича и делала все, чтобы он имел возможность плодотворно работать.

Дети Марка Иосифовича и Аси Моисеевны, Семен и Михаил, стали математиками. Их профессиональные интересы, как и интересы Марка Иосифовича, связаны с дифференциальными уравнениями.

Интересы и увлечения Марка Иосифовича были чрезвычайно разнообразными: музыка, литература, спорт, туризм. Но доминирующим всегда оставалось увлечение очередными математическими проблемами. Он был очень азартным в работе и спорте: для него были важны не только научные достижения, но и победы в теннисе!

Таким, увлеченным и преданным главному делу своей жизни - математике, благожелательным к окружающим, мы и будем всегда его помнить.

М.С. Агранович, А.В. Бабин, А.С. Демидов, Ю.А. Дубинский, А.И. Комеч, С.Б. Куксин, А.П. Кулешов, В.П. Маслов, С.П. Новиков, В.М. Тихомиров, А.В. Фурсиков, В.В. Чепыжов, А.И. Шнирельман, М. А. Шубин, Г. И. Эскин 